\title{
Pharmaceutical pollution of aquatic environment: an emerging and enormous challenge
}

\author{
Piotr Rzymski ${ }^{1}$, Agnieszka Drewek ${ }^{2}$, Piotr Klimaszyk ${ }^{2}$ \\ ${ }^{1}$ Department of Environmental Medicine, Poznań University of Medical Sciences, Rokietnicka 8, 60-806 Poznań, Poland, \\ e-mail: rzymskipiotr@ump.edu.pl (corresponding author) \\ ${ }^{2}$ Department of Water Protection, Adam Mickiewicz University, Umultowska 89, 61-614 Poznań, Poland, e-mail: pklim@amu.edu.pl
}

\begin{abstract}
The global use of pharmaceuticals is on the systematic rise and leads to contamination of surface waters with xenobiotic compounds with a wide range of bioactivity. Waters that receive urban and medical effluents are particularly threatened. The presence of pharmaceuticals in these ecosystems can lead to unpredictable ecological impacts and responses, and may also have an impact on human health. At the same time the identification and quantification of these chemicals, to a large extent remains a subject to scientific investigation than part of a thorough monitoring programme. Their biological effects on aquatic organisms are mainly recognized experimentally and often using concentrations far exceeding environmentally relevant levels. This review paper defines the main sources of pharmaceuticals in the aquatic environment, discusses the fate of these compounds and summarizes the current state-of-the-art of pharmaceutical monitoring in Polish surface waters.
\end{abstract}

Key words: pharmaceutical pollution, surface waters, effluents, environmental fate

\section{Introduction}

Water pollution is a broad environmental issue related to the discharge of various chemical compounds and the dispersion of pathogens from a vast number of human activities. Not only is it responsible for a decrease in the ecological function of aquatic habitats but it can also be a leading cause of disease and mortality in some regions (WHO/UNICEF 2015). Over the years, numerous studies have assessed the contamination of surface waters with various biological agents such as coliforms (Koczura et al. 2015), viruses (Huang et al. 2016), protozoan parasites (Słodkowicz-Kowalska et al. 2015), and chemicals, including fertilizers (O’Neil et al. 2012), toxic metals (Rzymski et al. 2014), arsenic (Yan et al. 2016), pesticides (Rzymski et al. 2013), perchlorate (Kannan et al. 2009), polycyclic aromatic hydrocarbons and polychlorinated biphenyls (Wolska et al. 2014). Recent decades have, however, given rise to a novel issue, namely, the emission of pharmaceuticals and their potential environmental resistance. This so called "drug pollution" or "pharmaceutical pollution" may have distinctive consequences on aquatic biota but estimation of these effects is yet to be fully elucidated (Pal et al. 2014; Obimakinde et al. 2017).
Under no circumstances should pharmaceutical pollution be ignored or regarded as an atypical environmental issue. With the development of medicine, the global use of various pharmaceutical drugs has steadily increased. In 2015, revenue from the worldwide pharmaceutical market reached 1072 billion \$ with the greatest share in North America (Statista 2016). A great variety of medications are currently available on the market and include, among many, analgesics (painkillers), antipyretics (fever reducers), antibiotics, antiseptics, hormone replacements, contraceptives, statins, mood stabilizers, antidepressants, and cytostatics. The bioactive compounds of these pharmaceuticals may have a natural origin (derived from microbes, plants or animals), or they may be solely chemically synthesized or derived from genetic engineering. All in all, over 4000 pharmaceuticals are currently in use for medical and veterinary purposes, and in agriculture as part of growth promotion of livestock (Boxall et al. 2012). As forecasted, by 2020 the global use of medicines is estimated to reach 4.5 trillion doses worth a total of 1.4 trillion \$ (IMS 2015).

Such an enormous and global use of medication, their varying types and physicochemical properties significantly contribute to the release of active pharmaceu- 
tical ingredients (APIs) and their metabolites to the environment, including surface waters. It is important to note that this release is rather unavoidable considering the current and forecasted use of pharmaceutical drugs. The European Union recognizes pharmaceutical residues in the environment as "priority substances", similarly to other micropollutants (EU 2013). Many studies have reported the occurrence of APIs derived from e.g. antibiotics, beta-blockers, anti-depressants, contraceptives, antiepileptic and anti-inflammatory drugs or antibiotics in surface and groundwater in the ppt and ppb concentration range (Herberer 2002; Cardoso et al. 2014; Barra Caracciolo et al. 2015). It is predicted that pharmaceutical pollution of water resources will be a key issue in the future protection of the environment as well as health of humans, unwittingly exposed mostly via contaminated water and food. A great number of chemical compounds used for the production of medications and various processes of transformation which they may undergo, complicate the ability to comprehensively identify APIs and evaluate the total risks arising from their occurrence in the environment. These challenges are yet to be faced.

\section{Sources of pharmaceuticals in the environment}

Five general sources of pharmaceuticals in the environment are established:

- raw and treated effluents from manufacturing sites;

- hospital waste;

- excretion by livestock treated with antibiotics, growth promoting agents and other formulations;

- runoff from agricultural fields fertilized with treated sewage sludge;

- excretion by humans and flushing of old and unwanted prescriptions.

Recent evidence has revealed high concentrations of a large number of pharmaceuticals in effluents from pharmaceutical factories and in receiving aquatic ecosystems (Cardoso et al. 2014). Wastewaters generated at such sites may contain APIs in concentrations ranging from several, hundreds to even thousands $\mathrm{mg} \mathrm{dm}^{-3}$ (Qiting and Xiheng 1988; Larsson et al. 2007; Sim et al. 2011). So far, over 130 different pharmaceuticals have been detected in effluents generated from pharmacological factories (Cardoso et al. 2014). A considerable number of these bioactive compounds survive classical treatment processes so concentrations in receiving

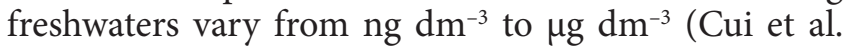
2006). For example, concentrations of the antibiotic oxytetracyclin in the River Xiao (China) at discharge point and $20 \mathrm{~km}$ downstream reached 641 and $250 \mu \mathrm{g}$ $\mathrm{dm}^{-3}$, respectively (Li et al. 2008). Insufficiently treated wastewaters from pharmaceutical production in one of the world's largest centres for bulk drug production located in India resulted in very high concentrations of ciprofloxacin (up to $6.5 \mathrm{mg} \mathrm{dm}^{-3}$ ), cetirizine (up to $1.2 \mathrm{mg} \mathrm{dm}^{-3}$ ), norfloxacin (up to $0.52 \mathrm{mg} \mathrm{dm}^{-3}$ ), and enoxacin (up to $0.16 \mathrm{mg} \mathrm{dm}^{-3}$ ) in freshwater lakes (Fick et al. 2009). In Germany, dimethylaminophenazone, an analgesic drug, was detected in groundwater from areas of former drug manufacturing at a mean level of $0.9 \mu \mathrm{g} \mathrm{dm}^{-3}$ despite being banned in 1978 by German authorities due to adverse health effects and its potential to form carcinogenic metabolites (Reddersen et al. 2002). It should be stressed that in Europe effluents from pharmacological manufacturing were generally estimated to account for just $2 \%$ of the total pharmaceuticals found in the environment (BIO Intelligence Service 2013) indicating their effective management by selective application of available treatment technologies (Caldwell et al. 2016).

The other route of release of pharmaceuticals to the environment, which is their use in animal breeding and subsequent excretion by livestock, has been less studied but can by no means be neglected due to an extensive list of compounds registered as veterinary drugs. Moreover, some of the medications used currently in the livestock industry had been previously approved for humans but banned due to adverse effects. One should note that as long as pharmaceuticals excreted by humans mostly reach wastewater plants and their concentrations can be decreased to some extent during treatment processes, veterinary drugs are more likely to reach the aquatic environment directly (Khetan and Collins 2009). The manure which is a popular crop fertilizer may contain high concentrations of APIs (e.g. veterinary antimicrobials). Moreover, in many regions use of treated sewage sludge (which may contain pharmaceuticals and transformation products) is approved as a fertilizer in agriculture (Jelic et al. 2011). This leads to their subsequent presence in surface runoff and groundwater, and eventual transport to water bodies and streams near intensive cattle feeding operations (Sura et al. 2015; Łukaszewicz et al. 2016).

Finally, the administration of medicines to humans results in their excretion, primarily with urine, in unaltered form or as an active metabolite. There are two phases of biotransformation of APIs in humans. The first leads to the introduction of a functional group such as hydroxyl, carboxyl, amine or sulfhydryl and increase hydrophilicity. The second phase involves conjugation with polar molecules such as glucuronic acid, acetate esters, carboximides or sulfate. These metabolites are eliminated by renal excretion (Kalgutkar et al. 2002). In fact, administration of a single drug can lead to excretion of its different forms. For example, only 15\% of ibuprofen is excreted unaltered or conjugated with 
glucuronide, the rest is excreted as carboxy-hydratropic acid, hydroxy-ibuprofen, carboxy-ibuprofen and their respective conjugates (Ternes et al. 2004). The amount of excretion depends on the rate of metabolism which varies between pharmaceuticals but usually falls within the range of $30-70 \%$ of an orally ingested dose (Bound and Voulvoulis 2005). For externally applied ointments or gels, washing off with water (e.g. during a bath) may occur. It has been widely reported that domestic sewage contains high concentrations of APIs and that in many cases, they are not effectively removed by wastewater treatment plants (Herberer 2002; Cardoso et al. 2014; Barra Caracciolo et al. 2015). Even greater pharmaceutical concentrations were noted in wastewater generated by hospitals advocating the consideration of specific treatments for such effluents before being discharged into the public sewage system (Mendoza et al. 2015). All in all, insufficient removal of APIs at wastewater treatment plants eventually leads to their discharge into the aquatic environment, mostly rivers and streams which serve as receivers for treated wastewater.

\section{Fate of pharmaceuticals in the freshwater environment}

There is no universal fate of APIs released to the aquatic environment (Fig. 1). After being excreted with wastewater they may undergo transformation at wastewater treatment plants. At this stage, transformation of some pharmaceuticals may result in compounds exhibiting greater toxicity and displaying increased persistence (Celiz et al. 2009). Furthermore, the concentrations of transformation products in water may be even higher than the parent compound as proven for carbamazepine, diclofenac and atorvastin (Langford and Thomas 2011). The scenario under which the concentrations of the parent compound are below detection limits but its transformation products are frequently present also needs to be taken into account (Jakimska et al. 2014).

The elimination of APIs and its dynamics in the aquatic environment depend on a number of key factors. The most important are:

- inherent physicochemical properties of the pharmaceutical;

- (sun) light availability;

- temperature;

- $\mathrm{pH}$

- oxygen availability;

- microbial communities.

The main elimination processes of APIs in the aquatic environment include photodegradation and biodegradation (Fig. 1). The former is possible as various pharmaceuticals contain heteroatoms, aromatic rings and other structures that can absorb light (direct pho-

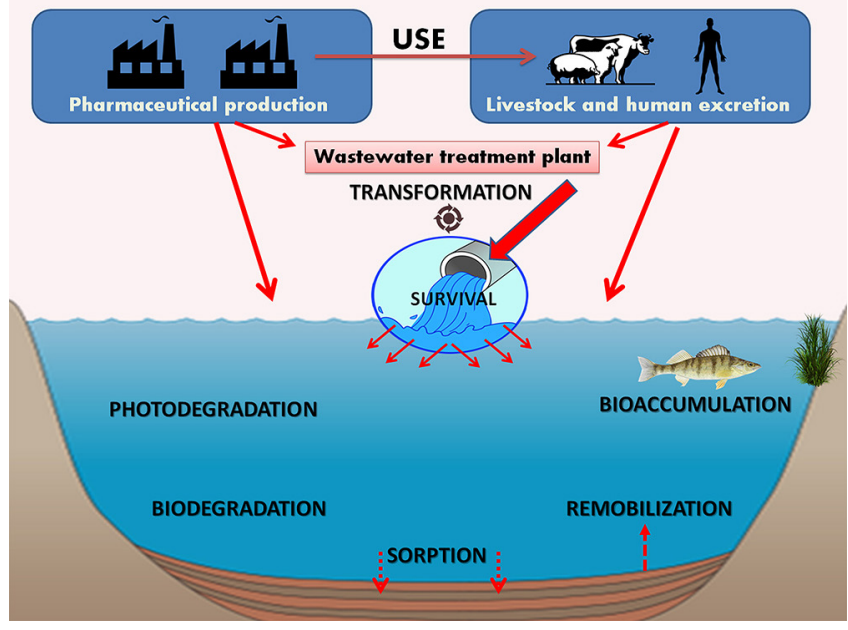

Fig. 1. Main sources and fate of pharmaceuticals in the aquatic environment

tolysis) or react with photogenerated transient species (indirect photolysis) (Khetan and Collins 2007). The microbial communities which are involved in pharmaceutical degradation in aquatic environments are not well known although it has been suggested that in surface waters biodegradation contributes to the elimination of APIs to a lesser extent than photodegradation (Khetan and Collins 2007). Identification of strains involved in biodegradation is of particular value as they could be potentially applied in the biological treatment of APIs in wastewater.

The other route for the removal of pharmaceuticals from water is their sorption to sediments - the process depends on pharmaceutical and sediment type (Scheytt et al. 2005). A recent study on five pharmaceuticals reported that their sorption to natural sediments decreases in the following order bendroflumethiazide $>$ oxazepam $>$ carbamazepine $>$ diclofenac $>$ furosemide $($ Svahn and Björklund 2015). Some of the initially sorbed APIs may potentially undergo desorption, although the exact conditions controlling the re-mobilization of pharmaceuticals in different types of aquatic environment are not fully elucidated (Martínez-Hernández et al. 2015).

The persistence of pharmaceuticals has not yet been completely ascertained (Bu et al. 2016). The United Nations Environmental Programme (UNEP) sets half-life at 60 days to define a chemical as persistent in the aquatic environment. It is obvious that pharmaceutical persistence is a combination of the inherited physicochemical properties of the compound and various environmental conditions. Experimental and in-field studies on the persistence of APIs yield varying and often contradictory results. For example, half-life for carbamazepine during laboratory and in-field research has been reported to vary from 3.5 to 233 days (Yamamoto et al. 2009) and from 63 to 1200 days, respectively (Tixer et al. 2003, Zou 
et al. 2015). All studies on diclofenac reported half-life below the threshold of 60 days ( $\mathrm{Bu}$ et al. 2016) but for ibuprofen half-life in experimental studies was in the range of 19-413 days depending on applied conditions (Yamamoto et al. 2009). It should be noted that pharmaceuticals can be continuously released to aquatic environments from wastewater treatment plants and thus their loading levels may exceed degradation rates, even if they are not very high. Therefore, pharmaceuticals are generally considered as a group of pseudo-persistent contaminants (Daughton et al. 2003).

The presence of APIs in surface waters leads to exposures of aquatic biota. Their effects have been studied predominantly for fish and include alterations in reproductive behaviour, aggression, boldness, activity, sociality and feeding rate (Brodin et al. 2014). The release of antibiotics triggers the development of antibiotic resistance genes and promotes an increase in antibiotic-resistant bacteria not only in hospital wastewaters and animal production wastewaters, but also in domestic wastewater, surface water and groundwater (Zhang et al. 2009).

Some APIs may also bioaccumulate and bioconcentrate in various aquatic organisms (Brodin et al. 2014). For example, the popular non-steroidal anti-inflammatory drugs, diclofenac, naproxen and ibuprofen, were all shown to accumulate in fish (Lahti et al. 2011). The concentration of ibuprofen determined in the fish plasma and bile samples was 100 to 1000 -fold higher than in corresponding water samples (Jeffries et al. 2015). Some antibiotics, particularly quinolones, can bioaccumulate at relatively high levels in molluscs ( $\mathrm{Li}$ et al. 2012). Anti-depressants were also found to bioaccumulate in periphyton, snails ( $\mathrm{Du}$ et al. 2015), benthic invertebrates (Grabicova et al. 2015), bivalves (Bringolf et al. 2010) and the muscles of fish species used for human consumption (Brooks et al. 2005). It should be noted that some APIs may easily be transferred through the trophic route, although their bioaccumulation in fish may be low due to efficient liver metabolism. Such observations have, for instance been made for propranolol which is a widely used beta-blocker (Ding et al. 2015) and the macrolide antibiotic roxithromycin (Liu et al. 2014). The body of knowledge on accumulation of pharmaceuticals in aquatic biota has extensively increased over the years, yet there remains a need to fully elucidate all transfer routes, estimate environmental and human risks, and screen the content of APIs in waterborne foodstuffs (Puckowski et al. 2016).

\section{The state-of-art for pharmaceutical pollution of water resources in Poland}

The monitoring of aquatic pollution with pharmaceutical bioactive components and their metabolites is not regulated in Poland, neither is their occurrence in raw or treated sewage and drinking water. A number of APIs have been detected in the influents and effluents of wastewater treatment plants with the greatest survival rate displayed by carbamazepine (concentrations up to $5128 \mathrm{ng} \mathrm{dm}^{-3}$ ), diclofenac (up to $5401 \mathrm{ng}$ $\mathrm{dm}^{-3}$ ), ifosfamide (up to $28 \mathrm{ng} \mathrm{dm}^{-3}$ ), furosemide (up to $1879 \mathrm{ng} \mathrm{dm}^{-3}$ ), hydrochlorothiazide (up to $4314 \mathrm{ng}$ $\mathrm{dm}^{-3}$ ), nafronyl (up to $14 \mathrm{ng} \mathrm{dm}^{-3}$ ), ramipril (up to 90

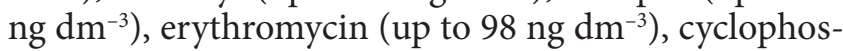
phamide (up to $24 \mathrm{ng} \mathrm{dm}^{-3}$ ), ranitidine (up to $982 \mathrm{ng}$ $\mathrm{dm}^{-3}$ ), and atenolol (up to $169 \mathrm{ng} \mathrm{dm}^{-3}$ ) (Kot-Wasik et al. 2016). Wastewaters in Poland were also reported to contain significant concentrations of ibuprofen (up to $74,000 \mathrm{ng} \mathrm{dm}^{-3}$ ) and naproxen (up to $117,000 \mathrm{ng} \mathrm{dm}^{-3}$ ) which reflects the popularity of these non-steroidal anti-inflammatory drugs in Poland (Kotowska et al. 2014). All in all, these findings unsurprisingly indicate that treated wastewater is an important route for the introduction of various xenobiotic pharmaceuticals to surface and groundwater. A recent study reported the

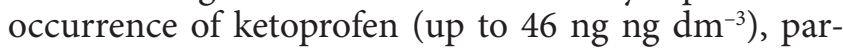
acetamol (up to $83 \mathrm{ng} \mathrm{ng} \mathrm{dm}^{-3}$ ) and naproxen (up to 21 ng $\mathrm{ng} \mathrm{dm}^{-3}$ ) in groundwater in the vicinity of Gdańsk (Caban et al. 2015). The general status of knowledge on the concentrations of various pharmaceuticals in Polish surface waters is still scarce. In recent years several investigations on both freshwaters (predominantly rivers as receivers of treated sewage) and drinking water have been conducted. The studied compounds, reported concentrations and investigated sites are summarized in Table 1. A number of APIs derived from cardiological (Giebułtowicz et al. 2016), immunosuppressive (Giebułtowicz and Nałęcz-Jawecki 2016), bactericidal (Wagil et al. 2014), non-steroid anti-inflammatory (Migowska et al. 2012) and psychiatric drugs (Giebułtowicz and Nałęcz-Jawecki 2014) have been successfully identified. Although the determined APIs concentrations are in the ppt range, one should note that these compounds are specifically designed to be bioactive at low concentrations. The available data clearly indicate that pharmaceutical pollution is an emerging problem in Poland and that a variety of APIs, at different concentrations, are present in Polish freshwaters. This is not surprising given the fact that Poland is currently the sixth largest pharmaceutical market in $\mathrm{Eu}-$ rope, worth over 34 billion PLN (approx. 8 billion EUR) in 2015 and undergoing a systematic increasing trend in recent years (IMS 2015). The greatest concentrations in Polish rivers have so far been reported for the cardiological drugs: valsartan, furosemide, telmisartan, hydrochlorothiazide, metoprolol and sotalol, and nonsteroidal anti-inflammatory drugs such as naproxen and diclofenac, analgesic compounds metamizole and 
Table 1. List of detected pharmaceuticals in Polish rivers and their maximum determined concentrations

\begin{tabular}{|c|c|c|c|c|}
\hline Pharmaceutical group & $\begin{array}{c}\text { Active } \\
\text { pharmaceutical } \\
\text { ingredient }\end{array}$ & $\begin{array}{l}\text { Studied } \\
\text { river }\end{array}$ & $\begin{array}{c}\begin{array}{c}\text { Maximum } \\
\text { detected } \\
\text { concentration }\end{array} \\
{\left[\mathrm{ng} \mathrm{dm}^{-3}\right]} \\
\end{array}$ & References \\
\hline \multirow{3}{*}{$\begin{array}{l}\text { Cardiovascular drugs: } \\
\text { Calcium channel blockers }\end{array}$} & Amlodipine & \multirow[t]{3}{*}{ Vistula } & 19 & \multirow[t]{8}{*}{ Giebułtowicz et al. 2016} \\
\hline & Diltiazem & & 24 & \\
\hline & Nifedipine & & 0.5 & \\
\hline \multirow{2}{*}{$\begin{array}{l}\text { Cardiovascular drugs: } \\
\text { Angiotensin-converting enzyme inhibitors }\end{array}$} & Quinalapril & \multirow[t]{2}{*}{ Vistula } & 155 & \\
\hline & Ramipril & & 73 & \\
\hline \multirow{4}{*}{$\begin{array}{l}\text { Cardiovascular drugs: } \\
\text { Angiotensin II receptor antagonist }\end{array}$} & Losartan & \multirow[t]{2}{*}{ Vistula } & 610 & \\
\hline & Telmisartan & & 1130 & \\
\hline & \multirow[t]{2}{*}{ Valsartan } & Vistula & 5260 & \\
\hline & & Warta & 133 & Kasprzyk-Hordern et al. 2007 \\
\hline \multirow{2}{*}{$\begin{array}{l}\text { Cardiovascular drugs: } \\
\text { diuretics }\end{array}$} & Furosemide & \multirow[t]{2}{*}{ Vistula } & 2670 & \multirow[t]{2}{*}{ Giebułtowicz et al. 2016} \\
\hline & Hydrochlorothiazide & & 1270 & \\
\hline \multirow{8}{*}{ Cardiovascular drugs: beta-blockers } & Acebutolol & \multirow[t]{7}{*}{ Vistula } & 643 & \multirow[t]{7}{*}{ Giebułtowicz et al. 2016} \\
\hline & Atenolol & & 205 & \\
\hline & Bisoprolol & & 1470 & \\
\hline & Labetalol & & 3.3 & \\
\hline & Propranolol & & 69 & \\
\hline & Sotalol & & 2120 & \\
\hline & \multirow[t]{2}{*}{ Metoprolol } & & 2190 & \\
\hline & & Warta & 155 & Kasprzyk-Hordern et al. 2007 \\
\hline Cardiovascular drugs: antriarrhytmics & Propafenone & Vistula & 87 & Giebułtowicz et al. 2016 \\
\hline \multirow{7}{*}{$\begin{array}{l}\text { Cardiovascular drug: } \\
\text { Lipid-regulating agents }\end{array}$} & Atorvastatin & Vistula & 114 & \multirow[t]{7}{*}{ Giebułtowicz et al. 2016} \\
\hline & Bezafibrate & Vistula & 4.5 & \\
\hline & & Warta & 8.0 & \\
\hline & Ciprofibrate & \multirow[t]{4}{*}{ Vistula } & 60 & \\
\hline & Clofibric acid & & 130 & \\
\hline & Fenofibrate & & 0.9 & \\
\hline & Gemfibrozil & & 3.0 & \\
\hline \multirow[t]{2}{*}{ Immunosuppressive drugs } & \multirow[t]{2}{*}{ Mycophenolic acid } & Vistula & 180 & \multirow{2}{*}{$\begin{array}{l}\text { Giebułtowicz and Nałęcz-Jawecki } \\
2016\end{array}$} \\
\hline & & Utrata & 130 & \\
\hline \multirow[t]{14}{*}{ Non-steroidal anti-inflammatory drugs } & Ketoprofen & Wierzyca & 25 & Migowska et al. 2012 \\
\hline & & Warta & 47 & Kasprzyk-Hordern et al. 2008 \\
\hline & Ibuprofen & & 76 & Baranowska and Kowalski 2012 \\
\hline & Diclofenac & & 486 & \\
\hline & & Oder & 470 & \\
\hline & & Vistula & 140 & \\
\hline & & Kłodnica & 70 & \\
\hline & Naproxen & Warta & 130 & \\
\hline & & Oder & 140 & \\
\hline & & Vistula & 300 & \\
\hline & & Kłodnica & 850 & \\
\hline & & Brda & 180 & \\
\hline & Aspirin & Oder & 730 & Baranowska and Kowalski 2012 \\
\hline & & Vistula & 400 & \\
\hline Analgesic & Paracetamol & Warta & 90 & \\
\hline & Metamizole & Oder & 900 & \\
\hline & Tramadol & Warta & 2108 & Kasprzyk-Hordern et al. 2007 \\
\hline & Codeine & & 15 & \\
\hline Seizure & Carbamazepine & Warta & 794 & \\
\hline & Gabapentin & & 75 & \\
\hline
\end{tabular}




\begin{tabular}{|c|c|c|c|c|}
\hline Pharmaceutical group & $\begin{array}{c}\text { Active } \\
\text { pharmaceutical } \\
\text { ingredient }\end{array}$ & $\begin{array}{l}\text { Studied } \\
\text { river }\end{array}$ & $\begin{array}{c}\begin{array}{c}\text { Maximum } \\
\text { detected } \\
\text { concentration }\end{array} \\
{\left[\mathrm{ng} \mathrm{dm}^{-3}\right]}\end{array}$ & References \\
\hline \multirow[t]{15}{*}{ Anti-depressants } & Citalopram & Vistula & 17.0 & \multirow{15}{*}{$\begin{array}{l}\text { Giebułtowicz and Nałęcz-Jawecki } \\
2014\end{array}$} \\
\hline & & Utrata & 4.0 & \\
\hline & Doxepin & Vistula & 1.9 & \\
\hline & \multirow[t]{2}{*}{ Fluoxetine } & Vistula & 3.2 & \\
\hline & & Utrata & 5.5 & \\
\hline & \multirow[t]{2}{*}{ Mianserin } & Vistula & 9.0 & \\
\hline & & Utrata & 7.0 & \\
\hline & \multirow[t]{2}{*}{ Mirtazepin } & Vistula & 5.0 & \\
\hline & & Utrata & 2.3 & \\
\hline & \multirow[t]{2}{*}{ Moclobemid } & Vistula & 28 & \\
\hline & & Utrata & 45 & \\
\hline & Tianeptin & \multirow[t]{2}{*}{ Vistula } & 1.8 & \\
\hline & Trazodon & & 0.9 & \\
\hline & \multirow[t]{2}{*}{ Venlaflaxin } & Vistula & 250 & \\
\hline & & Utrata & 140 & \\
\hline \multirow[t]{4}{*}{ Anthelmintic veterinary drugs } & Flubendazole & \multirow[t]{4}{*}{ Gościcina } & 39.2 & \multirow{4}{*}{$\begin{array}{l}\text { Wagil et al. 2015a, Wagil et al. } \\
\text { 2015b, Wagil et al. 2015c }\end{array}$} \\
\hline & Fenbendazole & & 85.7 & \\
\hline & Metronidazole & & 136.2 & \\
\hline & Doramectin & & 1.92 & \\
\hline Synthetic non-steroidal estrogens & Diethylstilbestrol & Wierzyca & 8 & Migowska et al. 2012 \\
\hline \multirow[t]{8}{*}{ Antibiotics } & \multirow[t]{2}{*}{ Ciprofloxacin } & Reda & 40.7 & Wagil et al. 2014 \\
\hline & & Gościcina & 2745 & \\
\hline & Enrofloxacin & Gościcina & 248.7 & \\
\hline & \multirow[t]{2}{*}{ Norfloxacin } & Reda & 146.5 & \\
\hline & & Gościcina & 442.8 & \\
\hline & Sulfamethoxazole & Warta & 60 & Kasprzyk-Hordern et al. 2007 \\
\hline & Sulfapyridine & & 31 & \\
\hline & Trimethoprim & & 27 & \\
\hline
\end{tabular}

tramadol, seizure drug carbamazepine and the antibiotic norfloxacin (Table 1). Moreover, some studies have assessed the presence of veterinary drugs, particularly those designed to expel parasitic worms (Wagil et al. 2015a, Wagil et al. 2015b, Wagil et al. 2015c). One study has also detected diethylstilbestrol in river waters, the non-steroidal synthetic estrogen once used as a human drug and transferred to veterinary medicine as a growth promoting agent after its carcinogenic and teratogenic activity was evidenced (Migowska et al. 2012).

At the same time the problem of pharmaceutical pollution appears to be only superficially recognized in Poland as:

- no data on API concentrations are available for Polish lakes;

- no data are available on the potential effects of API occurrence in Polish freshwaters;

- identification of APIs in freshwaters in Poland remains more a subject to scientific investigation than part of a thorough monitoring programme.

The presence and concentrations of APIs in freshwaters can be prone to various effects such as number of generated wastewaters and efficiency of wastewater treatment plants, distance from the point of treated wastewater discharge, seasonality, physicochemical properties of water, and microbial community. The exact effect of these parameters on API concentrations in Poland remains yet to be comprehensively studied. As shown, the concentration of APIs in rivers significantly decreases downstream from the point of wastewater discharge while their concentrations may vary during the year. For example, the greatest concentration of the immunosuppressive agent, mycophenolic acid, in the River Vistula was found during spring (Giebułtowicz and Nałęcz-Jawecki 2016) whereas veterinary drugs from the group of benzimidazoles, designed to treat intestinal parasites, only occurred in river samples (River Gościnna in northern Poland) collected during autumn (Wagil et al. 2015c). Considering that treated wastewater is a significant route through which APIs reach the environment, their concentrations in surface waters are likely to reflect the popularity and seasonal use of certain medications (Kot-Wasik et al. 2016). This strongly advocates monitoring studies to be conducted continuously during the year rather than during a specific season. 
Table 2. List of detected pharmaceuticals in drinking water distributed in Poland and their maximum determined concentrations

\begin{tabular}{|c|c|c|c|c|}
\hline \multirow[t]{2}{*}{ Pharmaceuticals } & \multirow{2}{*}{$\begin{array}{c}\text { Active } \\
\text { pharmaceutical } \\
\text { ingredient }\end{array}$} & $\begin{array}{l}\text { Maximum detected } \\
\text { concentration }\end{array}$ & \multirow{2}{*}{$\begin{array}{l}\text { Detected } \\
\text { locations }\end{array}$} & \multirow[t]{2}{*}{ References } \\
\hline & & {$\left[\mathrm{ng} \mathrm{dm}^{-3}\right]$} & & \\
\hline \multirow[t]{21}{*}{ Cardiological } & Acebutolol & 4.0 & Warsaw & Giebułtowicz et al. 2016 \\
\hline & Amlodipine & 3.5 & Warsaw & \\
\hline & Atorvastatin & 0.3 & Warsaw & \\
\hline & Bisoprolol & 17.0 & Warsaw & \\
\hline & Clofibric acid & 1.3 & Warsaw & \\
\hline & Diltiazem & 1.4 & Warsaw & \\
\hline & Fenofibrate & 1.1 & Warsaw & \\
\hline & Furosemide & 29 & Warsaw & \\
\hline & Losartan & 5.0 & Warsaw & \\
\hline & Metoprolol & 14 & Warsaw & \\
\hline & Propafenone & 4.0 & Warsaw & \\
\hline & Propranolol & 7.0 & Warsaw & \\
\hline & Quinalapril & 1.8 & Warsaw & \\
\hline & Sotalol & 16 & Warsaw & \\
\hline & Telmisartan & 23 & Warsaw & \\
\hline & Valsartan & 27 & Warsaw & \\
\hline & Trimetazidine & 4.2 & Gdańsk & Kot-Wasik et al. 2016 \\
\hline & Nafronyl & 3.8 & & \\
\hline & Ramipril & 2.8 & $\begin{array}{l}\text { Gdańsk } \\
\text { Warsaw }\end{array}$ & $\begin{array}{l}\text { Kot-Wasik et al. 2016; } \\
\text { Giebułtowicz et al. } 2016\end{array}$ \\
\hline & Hydrochlorothiazide & 26 & $\begin{array}{l}\text { Gdańsk } \\
\text { Warsaw }\end{array}$ & \\
\hline & Atenolol & 1.5 & $\begin{array}{l}\text { Gdańsk } \\
\text { Warsaw }\end{array}$ & \\
\hline \multirow[t]{4}{*}{ Anti-depressants } & Citalopram & 1.5 & \multirow[t]{4}{*}{ Warsaw } & \multirow{4}{*}{$\begin{array}{c}\text { Giebułtowicz and Nałęcz- } \\
\text { Jawecki } 2014\end{array}$} \\
\hline & Mianserin & 0.9 & & \\
\hline & Moclobemid & 0.3 & & \\
\hline & Venlaflaxin & 1.9 & & \\
\hline Anti-diabetic & Metformin & 8.0 & Gdańsk & Kot-Wasik et al. 2016 \\
\hline Gastric & Ranitidine & 5.6 & & \\
\hline Analgesic & Paracetamol & 118.9 & Gdańśk & Caban et al. 2015 \\
\hline \multirow[t]{2}{*}{ Antibiotics } & Erythromycin & 6.0 & \multirow[t]{2}{*}{ Gdańsk } & Kot-Wasik et al. 2016 \\
\hline & Chloramphenicol & 0.9 & & \\
\hline Seizure & Carbamazepine & 6.0 & Gdańsk & \\
\hline Contraceptives & Levonorgestrel & 46.4 & Gdańśk & \\
\hline Hormone replacement & Progesteron & 4.8 & Gdańśk & \\
\hline \multirow[t]{3}{*}{ Non-steroidal anti-inflammatory drugs } & Ketoprofen & 166.9 & \multirow[t]{3}{*}{ Gdańśk } & \\
\hline & Ibuprofen & 223.6 & & \\
\hline & Diclofenac & 114.3 & & \\
\hline
\end{tabular}

To date, the presence of APIs in sediments or aquatic biota has only been assessed very sporadically in Polish waters. Metronidazol was detected up to 12.0 $\mathrm{ng} \mathrm{g}^{-1}$ in river sediments and $1.5 \mathrm{ng} \mathrm{g}^{-1}$ in the muscle tissue of rainbow trout (Wagil et al. 2015a, Wagil et al. 2015b, Wagil et al. 2015c). Three antibiotics from the group of fluoroquinolones, enrofloxacin, norfloxacin and ciprofloxacin, were determined in muscle tissues of rainbow trout from fish farms at maximum concentrations of 22, 60 and $18.5 \mathrm{ng} \mathrm{g}^{-1}$, respectively (Wagil et al. 2014). The presence of ibuprofen, diclofenac, salicylic acid and $17 \beta$-estradiol were reported in sediments col- lected from fish ponds (Kumirska et al. 2015). Further research on the sedimentary content of pharmaceuticals in different surface waters in Poland as well as in aquatic biota, including that which is harvested for human consumption, is urgently needed.

The occurrence of some of the above-mentioned pharmaceuticals was also screened in samples of tap water. The list of APIs which were quantified with maximum reported concentrations are given in Table 2 . The greatest concentrations were determined for nonsteroidal anti-inflammatory drugs (ketoprofen, ibuprofen and diclofenac) and paracetamol which again cor- 
responds to the popularity of these pharmaceuticals in Poland. To date, the presence of APIs has, however, only been evaluated for tap water from Warsaw and Gdańsk; the presence of pharmaceuticals and their concentrations in drinking water from other Polish locations remains to be studied. The determined concentrations fall within the ppt range (Table 2), thus one could assume they are unlikely to have any adverse effect in humans. Nevertheless, the pharmaceuticals do not appear on their own but as a combination of compounds displaying different bioactive properties. Therefore, their additive and synergistic effects cannot be excluded. Furthermore, human exposure to pharmaceuticals has a life-long character; its effects on health are unknown. Finally, the low concentrations could still be potentially harmful in more vulnerable populations and during early stages of development (e.g. during the fetal period). Although this effect is still to be comprehensively studied, the precautionary principle in this regard must be the guiding one. A further effort is required to screen APIs in water used for human purposes in Poland. These challenges, however, require interdisciplinary and complex efforts, and a great deal of financial and legislative support. The presence of pharmaceuticals in drinking water, even at very low concentrations, should raise reasonable concerns among stakeholders such as drinking-water regulators, governments, water suppliers and the public, with regard to the potential risks to humans. Despite the unavoidable character of pharmaceutical pollution, an effort should be made to maximally decrease the release of APIs to the environment, particularly by the maximum possible increase in the effectiveness of wastewater treatment processes.

\section{Conclusions}

Pharmaceutical pollution is a serious and widespread problem which has been recognized globally and given attention by environmental chemists and ecotoxicologists. The increasing occurrence of APIs in aquatic environments can adversely affect living organisms on different organizational levels and lead to alterations in the ecological function of rivers and lakes. Further, contamination of drinking water sources with these compounds may lead to unintended human exposures and potential effects on health. Pharmaceutical pollution will be an increasing challenge for environmental protection, if one considers the forecasted systematic increase in the use of various medications by the human population. Therefore, it is imperative to support systematic research on API detection methods and to monitor the great number of APIs in wastewater, surface and groundwater and tap water.

\section{References}

Baranowska I., Kowalski B., 2012, A rapid UHPLC method for the simultaneous determination of drugs from different therapeutic groups in surface water and wastewater, Bull. Environ. Contam. Toxicol. 89(1): 8-14.

Barra Caracciolo A., Topp E., Grenni P., 2015, Pharmaceuticals in the environment: biodegradation and effects on natural microbial communities. A review, J. Pharm. Biomed. Anal. 106: 25-36.

BIO Intelligence Service, 2013, Study on the environmental risks of medicinal products, Final Report prepared for Executive Agency for Health and Consumers. Retrieved from http://ec.europa.eu/health/files/environment/ study_environment.pdf [accessed 10 April 2017].

Bound J.P., Voulvoulis N., 2005, Household disposal of pharmaceuticals as a pathway for aquatic contamination in the United Kingdom, Environ. Health Perspect. 113(12): 1705-1711.

Boxall A.B., Rudd M.A., Brooks B.W., Caldwell D.J., Choi K., Hickmann S., Innes E., Ostapyk K., Staveley J.P., Verslycke T., Ankley G.T., Beazley K.F., Belanger S.E., Berninger J.P., Carriquiriborde P., Coors A., Deleo P.C., Dyer S.D., Ericson J.F., Gagné F., Giesy J.P., Gouin T., Hallstrom L., Karlsson M.V., Larsson D.G., Lazorchak J.M., Mastrocco F., McLaughlin A., McMaster M.E., Meyerhoff R.D., Moore R., Parrott J.L., Snape J.R., Murray-Smith R., Servos M.R., Sibley P.K., Straub J.O., Szabo N.D., Topp E., Tetreault G.R., Trudeau V.L., Van Der Kraak G., 2012, Pharmaceuticals and personal care products in the environment: what are the big questions?, Environ. Health Perspect. 120(9): 1221-1229.

Bringolf R.B., Heltsley R.M., Newton T.J., Eads C.B., Fraley S.J., Shea D., Cope W.G., 2010, Environmental occurrence and reproductive effects of the pharmaceutical fluoxetine in native freshwater mussels, Environ. Toxicol. Chem. 29(6): 1311-1318.

Brodin T., Piovano S., Fick J., Klaminder J., Heynen M., Jonsson M., 2014, Ecological effects of pharmaceuticals in aquatic systems - impacts through behavioural alterations, Philos. Trans. R. Soc. Lond. B 369(1656): 20130580.

Brooks B.W., Chambliss C.K., Stanley J.K., Ramirez A., Banks K.E., Johnson R.D., Lewis R.J., 2005, Determination of select antidepressants in fish from an effluent-dominated stream, Environ. Toxicol. Chem. 24(2): 464-469.

Caban M., Lis E., Kumirska J., Stepnowski P., 2015, Determination of pharmaceutical residues in drinking water in Poland using a new SPE-GC-MS(SIM) method based on Speedisk extraction disks and DIMETRIS derivatization, Sci. Total. Environ. 538: 402-411.

Caldwell D.J., Mertens B., Kappler K., Senac T., Journel R., Wilson P., Meyerhoff R.D., Parke N.J., Mastrocco F., Mattson B., Murray-Smith R., Dolan D.G., Straub J.O., Wiedemann M., Hartmann A., Finan D.S., 2016, A risk-based approach to managing active pharmaceutical ingredi- 
ents in manufacturing effluent, Environ. Toxicol. Chem. 35(4): 813-822.

Cardoso O., Porcher J.M., Sanchez W., 2014, Factory-discharged pharmaceuticals could be a relevant source of aquatic environment contamination: review of evidence and need for knowledge, Chemosphere 115: 20-30.

Celiz M.D., Tso J., Aga D.S., 2009, Pharmaceutical metabolites in the environment: analytical challenges and ecological risks, Environ. Toxicol. Chem. 28(12): 2473-2484.

Cui C.W., Ji S.L., Ren H.Y., 2006, Determination of steroid estrogens in wastewater treatment plant of a controceptives producing factory, Environ. Monit. Assess. 121(13): 409-419.

Daughton C.G., 2003, Cradle-to-cradle stewardship of drugs for minimizing their environmental disposition while promoting human health. II. Drug disposal, waste reduction, and future directions, Environ. Health Perspect. 111(5): 775-785.

Ding J., Lu G., Li S., Nie Y., Liu J., 2015, Biological fate and effects of propranolol in an experimental aquatic food chain, Sci. Total. Environ. 532: 31-39.

Du B., Haddad S.P., Scott W.C., Chambliss C.K., Brooks B.W., 2015, Pharmaceutical bioaccumulation by periphyton and snails in an effluent-dependent stream during an extreme drought, Chemosphere. 119: 927-934.

[EU] European Union, 2013, Directive 2013/39/EU of the European Parliament and of the Council of 12 August 2013 amending Directives 2000/60/EC and 2008/105/EC as regards priority substances in the field of water policy, Offic. J. Eur. Union L226: 1-17.

Fick J., Söderström H., Lindberg R.H., Phan C., Tysklind M., Larsson D.G., 2009, Contamination of surface, ground, and drinking water from pharmaceutical production, Environ. Toxicol. Chem. 28(12): 2522-2527.

Giebułtowicz J., Nałęcz-Jawecki G., 2014, Occurrence of antidepressant residues in the sewage-impacted Vistula and Utrata rivers and in tap water in Warsaw (Poland), Ecotoxicol. Environ. Saf. 104: 103-109.

Giebułtowicz J., Nałęcz-Jawecki G., 2016, Occurrence of immunosuppressive drugs and their metabolites in the sewage-impacted Vistula and Utrata Rivers and in tap water from the Warsaw region (Poland), Chemosphere 148: 137-147.

Giebułtowicz J., Stankiewicz A., Wroczyński P., NałęczJawecki G., 2016, Occurrence of cardiovascular drugs in the sewage-impacted Vistula River and in tap water in the Warsaw region (Poland), Environ. Sci. Pollut. Res. 23: 24337-24349.

Grabicova K., Grabic R., Blaha M., Kumar V., Cerveny D., Fedorova G., Randak T., 2015, Presence of pharmaceuticals in benthic fauna living in a small stream affected by effluent from a municipal sewage treatment plant, Water Res. 72: 145-153.

Heberer T., 2002, Tracking persistent pharmaceutical residues from municipal sewage to drinking water, J. Hydrol. 266(3-4): 175-189.
Huang W.C., Chou Y.P., Kao P.M., Hsu T.K., Su H.C., Ho Y.N., Yang Y.C., Hsu B.M., 2016, Nested-PCR and TaqMan real-time quantitative PCR assays for human adenoviruses in environmental waters, Water Sci. Technol. 73(8): 1832-1841.

[IMS] IMS Institute for Healthcare Informatics, 2015, Global Use of Medicines in 2020: Outlook and Implications, 43 pp.

Jakimska A., Śliwka-Kaszyńska M., Reszczyńska J., Namieśnik J., Kot-Wasik A., 2014, Elucidation of transformation pathway of ketoprofen, ibuprofen, and furosemide in surface water and their occurrence in the aqueous environment using UHPLC-QTOF-MS, Anal. Bioanal. Chem. 406(15): 3667-3680.

Jeffries K.M., Brander S.M., Britton M.T., Fangue N.A., Connon R.E., 2015, Chronic exposure to low and high concentration of ibuprofen elicit different gene response patterns in a euryhaline fish, Environ. Sci. Pollut. Res. 22(22): 17397-17413.

Jelic A., Gros M., Ginebreda A., Cespedes-Sánchez R., Ventura F., Petrovic M., Barcelo D., 2011, Occurrence, partition and removal of pharmaceuticals in sewage water and sludge during wastewater treatment, Water Res. 45(3): 1165-1176.

Kalgutkar A.S., Dalvie D.K., O’Donnell J.P., Taylor T.J., Sahakian D.C., 2002, On the diversity of oxidative bioactivation reactions on nitrogen-containing xenobiotics, Curr. Drug Metab. 3(4): 379-424.

Kannan K., Praamsma M.L., Oldi J.F., Kunisue T., Sinha R.K., 2009, Occurrence of perchlorate in drinking water, groundwater, surface water and human saliva from India, Chemosphere 76(1): 22-26.

Kasprzyk-Hordern B., Dinsdale R.M., Guwy A.J., 2007, Multi-residue method for the determination of basic/ neutral pharmaceuticals and illicit drugs in surface water by solid-phase extraction and ultra performance liquid chromatography-positive electrospray ionisation tandem mass spectrometry, J. Chromatogr. A. 1161(1-2): 132-145.

Khetan S.K., Collins T.J., 2007, Human pharmaceuticals in the aquatic environment: a challenge to Green Chemistry, Chem. Rev. 107(6): 2319-2364.

Koczura R., Krysiak N., Taraszewska A., Mokracka J., 2015, Coliform bacteria isolated from recreational lakes carry class 1 and class 2 integrons and virulence-associated genes, J. Appl. Microbiol. 119(2): 594-603.

Kotowska U., Kapelewska J., Sturgulewska J., 2014, Determination of phenols and pharmaceuticals in municipal wastewaters from Polish treatment plants by ultrasoundassisted emulsification-microextraction followed by GCMS, Environ. Sci. Pollut. Res. 21(1): 660-673.

Kot-Wasik A., Jakimska A., Śliwka-Kaszyńska M., 2016, Occurrence and seasonal variations of 25 pharmaceutical residues in wastewater and drinking water treatment plants, Environ. Monit. Assess. 188(12): 661. 
Kumirska J., Migowska N., Caban M., Łukaszewicz P., Stepnowski P., 2015, Simultaneous determination of nonsteroidal anti-inflammatory drugs and oestrogenic hormones in environmental solid samples, Sci. Total Environ. 508: 498-505.

Lahti M., Brozinski J.M. Jylhä A. Kronberg L., Oikari A., 2011, Uptake from water, biotransformation, and biliary excretion of pharmaceuticals by rainbow trout, Environ. Toxicol. Chem. 30(6): 1403-1411.

Langford K., Thomas K.V., 2011, Input of selected human pharmaceutical metabolites into the Norwegian aquatic environment, J. Environ. Monitor. 13: 416-421.

Larsson D.G., de Pedro C., Paxeus N., 2007, Effluent from drug manufactures contains extremely high levels of pharmaceuticals, J. Hazard. Mater. 148(3): 751-755.

Li W., Shi Y., Gao L., Liu J., Cai Y., 2012, Investigation of antibiotics in mollusks from coastal waters in the Bohai Sea of China, Environ. Pollut. 162: 56-62.

Liu J., Lu G., Wang Y., Yan Z., Yang X., Ding J., Jiang Z., 2014, Bioconcentration, metabolism, and biomarker responses in freshwater fish Carassius auratus exposed to roxithromycin, Chemosphere 99: 102-108.

Łukaszewicz P., Maszkowska J., Mulkiewicz E., Kumirska J., Stepnowski P., Caban M., 2016, Impact of Veterinary Pharmaceuticals on the Agricultural Environment: A Reinspection, Rev. Environ. Contam. Toxicol. 243: 89-148.

Martínez-Hernández V., Meffe R., Herrera S., Arranz E., de Bustamante I., 2014, Sorption/desorption of non-hydrophobic and ionisable pharmaceutical and personal care products from reclaimed water onto/from a natural sediment, Sci. Total Environ. 472: 273-281.

Mendoza A., Aceña J., Pérez S., López de Alda M., Barceló D., Gil A., Valcárcel Y., 2015, Pharmaceuticals and iodinated contrast media in a hospital wastewater: A case study to analyse their presence and characterise their environmental risk and hazard, Environ. Res. 140: 225-241.

Migowska N., Caban M., Stepnowski P., Kumirska J., 2012, Simultaneous analysis of non-steroidal anti-inflammatory drugs and estrogenic hormones in water and wastewater samples using gas chromatography-mass spectrometry and gas chromatography with electron capture detection, Sci. Total Environ. 441: 77-88.

O’Neil J.M., Davis T.W., Burford M.A., Gobler C.J., 2012, The rise of harmful cyanobacteria blooms: the potential roles of eutrophication and climate change, Harmful Algae 14: 313-334.

Obimakinde S., Fatoki O., Opeolu B., Olatunji O., 2017, Veterinary pharmaceuticals in aqueous systems and associated effects: an update, Environ. Sci. Pollut. Res. 24(4): 3274-3297.

Pal A., He Y., Jekel M., Reinhard M., Gin K.Y., 2014, Emerging contaminants of public health significance as water quality indicator compounds in the urban water cycle, Environ. Int. 71: 46-62.

Puckowski A., Mioduszewska K., Łukaszewicz P., Borecka M., Caban M., Maszkowska J., Stepnowski P., 2016, Bio- accumulation and analytics of pharmaceutical residues in the environment: A review, J. Pharm. Biomed. Anal. 127: 232-255.

Qingwei B., Xiao S., Gang Y., Jun H., Bin W., 2016, Assessing the persistence of pharmaceuticals in the aquatic environment: Challenges and needs, Emerging Contaminants 2(3): 145-147.

Qiting J., Xiheng Z., 1988, Combination process of anaerobic digestion and ozonation technology for treating wastewater from antibiotics production, Water Treat. 3: 285-291.

Reddersen K., Heberer T., Dünnbier U., 2002, Identification and significance of phenazone drugs and their metabolites in ground- and drinking water, Chemosphere 49(4): 539-544.

Rzymski P., Klimaszyk P., Kubacki T., Poniedziałek B., 2013, The effect of glyphosate-based herbicide on aquatic organisms - a case study, Limnol. Rev. 13: 215-220.

Rzymski P., Niedzielski P., Klimaszyk P., Poniedziałek B., 2014, Bioaccumulation of selected metals in bivalves (Unionidae) and Phragmites australis inhabiting a municipal water reservoir. Environ. Monit. Assess. 186(5): 3199-3212.

Scheytt T., Mersmann P., Lindstädt R., Heberer T., 2005, Determination of sorption coefficients of pharmaceutically active substances carbamazepine, diclofenac, and ibuprofen, in sandy sediments, Chemosphere. 60(2): 245-253.

Sim W.J., Lee J.W., Lee E.S., Shin S.K., Hwang S.R., Oh J.E., 2011, Occurrence and distribution of pharmaceuticals in wastewater from households, livestock farms, hospitals and pharmaceutical manufactures, Chemosphere 82(2): 179-186.

Słodkowicz-Kowalska A., Majewska A.C., Rzymski P., Skrzypczak Ł., Werner A., 2015, Human waterborne protozoan parasites in freshwater bivalves (Anodonta anatina and Unio tumidus) as potential indicators of fecal pollution in urban reservoir, Limnologica 51: 32-36.

Statista, 2016, Revenue of the worldwide pharmaceutical market from 2001 to 2015 (in billion U.S. dollars). Retrieved from https://www.statista.com/statistics/263102/ pharmaceutical-market-worldwide-revenue-since-2001/ [accessed 10 April 2017].

Sura S., Degenhardt D., Cessna A.J., Larney F.J., Olson A.F., McAllister T.A., 2015, Transport of three veterinary antimicrobials from feedlot pens via simulated rainfall runoff, Sci. Total Environ. 521-522: 191-199.

Svahn O., Björklund E., 2015, Describing sorption of pharmaceuticals to lake and river sediments, and sewage sludge from UNESCO Biosphere Reserve Kristianstads Vattenrike by chromatographic asymmetry factors and recovery measurements, J. Chromatogr. A 1415: 73-82.

Ternes T.A., Joss A., Siegrist H., 2004, Scrutinizing pharmaceuticals and personal care products in wastewater treatment, Environ. Sci. Technol. 38(20): 392-399.

Tixier C., Singer H.P., Oellers S., Müller S.R., 2003, Occurrence and fate of carbamazepine, clofibric acid, di- 
clofenac, ibuprofen, ketoprofen, and naproxen in surface waters, Environ. Sci. Technol. 37(6): 1061-1068.

Wagil M., Białk-Bielińska A., Maszkowska J., Stepnowski P., Kumirska J., 2015a, Critical points in the evaluation of analytical methods based on liquid chromatography separation for the determination of doramectin in different environmental samples, Chemosphere 119 Suppl.: 9-15.

Wagil M., Kumirska J., Stolte S., Puckowski A.,, Maszkowska J., Stepnowski P. Białk-Bielińska A., 2014, Development of sensitive and reliable LC-MS/MS methods for the determination of three fluoroquinolones in water and fish tissue samples and preliminary environmental risk assessment of their presence in two rivers in northern Poland, Sci. Total Environ. 493: 1006-1013.

Wagil M., Maszkowska J., Białk-Bielińska A., Caban M., Stepnowski P., Kumirska J., 2015b, Determination of metronidazole residues in water, sediment and fish tissue samples, Chemosphere 119 Suppl.: 28-34.

Wagil M., Maszkowska J., Białk-Bielińska A., Stepnowski P., Kumirska J., 2015c, A comprehensive approach to the determination of two benzimidazoles in environmental samples, Chemosphere 119 Suppl.: 35-41.
WHO/UNICEF, 2015, Progress on sanitation and drinking water: 2015 update and MDG assessment, World Health Organization (WHO), Geneva, 80 pp.

Wolska L., Mechlińska A., Rogowska J., Namieśnik J., 2014, Polychlorinated biphenyls (PCBs) in bottom sediments: identification of sources, Chemosphere 111: 151-156.

Yamamoto H., Nakamura Y., Moriguchi S., Nakamura Y., Honda Y., Tamura I., Hirata Y., Hayashi A., Sekizawa J., 2009, Persistence and partitioning of eight selected pharmaceuticals in the aquatic environment: laboratory photolysis, biodegradation, and sorption experiments, Water Res. 43(2): 351-362.

Yan C., Che F., Zeng L., Wang Z., Du M., Wei Q., Wang Z., Wang D., Zhen Z., 2016, Spatial and seasonal changes of arsenic species in Lake Taihu in relation to eutrophication, Sci. Total Environ. 563-564: 496-505.

Zhang X.X., Zhang T., Fang H.H., 2009, Antibiotic resistance genes in water environment, Appl. Microbiol. Biotechnol. 82(3): 397-414.

Zou H., Radke M., Kierkegaard A., MacLeod M., McLachlan M.S., 2015, Using chemical benchmarking to determine the persistence of chemicals in a Swedish lake, Environ. Sci. Technol. 49(3): 1646-1653. 